\title{
Analysis on the Failure of Homosexual Marriage in China from the Perspective of Gender
}

\author{
${ }^{1}$ LinYi university, Ji'nan, China, 250000 \\ *Corresponding author. Email: qiaoleshui1028@163.com
}

Leshui Qiao, ${ }^{1, *}$

\begin{abstract}
Under the dual force of the resurgence of international conservatism and the human rights movement, democrats in China are increasingly calling for homosexual marriage, but the country still rejects the development of gay marriage rights on the grounds of non-traditional. This paper explores the reasons why traditional Confucianism, the patriarchy system and the socio-political system have failed to legalize homosexual marriage in China from the perspective of gender, in addtion, it further explores the plight of the Chinese gay community: the traditional Confucianism-led thinking on homosexual marriage obstacles are one-sided, the conspiracy between the patriarchy's aversion to same-sex behavior and the socialist ideology for opposing capitalist democracy are the root cause. This paper aims to explain the current delicate situation of homosexuality in China and the underlying reasons for its situation.
\end{abstract}

Keywords: homosexual marriage, patriarchy, ideology, Confucianism

\section{INTRODUCTION}

China is in a delicate environment of viewing the homosexual equal rights: in the past, China did not have a resistance to homosexuality like many Western Christian countries or Middle Eastern Muslim countries, nor did it have oppressive policies, that is, there was no discrimination against homosexuality. However, the status of homosexuality in modern China is in an awkward position. In the international arena, it has not achieved the freedom of homosexual marriage like in European and American countries, where homosexuality also has a certain influence in various aspects such as film and television culture. But compared with backward countries or the Middle East, in terms of legislation, the legal status has been affirmed, it has not received personal freedom persecution, but the identities are only restricted to the privacy domain, and their right to speak in the public domain is stigmatized and prohibited. In China, on March 14, 1997, the National People's Congress of the People's Republic of China revised the "Criminal Law of the People's Republic of China" to abolish the crime of hooliganism that vaguely criminalizes same-sex sexual behavior [1]. On April 20, 2001, the third edition of the "Chinese Mental Disorder Classification and Diagnosis Criteria" formulated by the Chinese Medical Association Psychiatric Association and others removed "self-congruent homosexuality" from it [2]. These two incidents are generally considered to mark the decriminalization and non-pathology of homosexuality in China [3], and since 2017, notary offices across mainland China have begun to open up to same-sex couples in accordance with the "General Principles of the Civil Law of the People's Republic of China" guardianship [4], in the private sphere, Chinese homosexuality is in a state of being isolated from social interaction. It does not cross the public sphere and needs to express continuous personality characteristics. It seems that there is only isolation can be tolerated. Gay groups in the public domain are immoral and they are not allowed to exist in the public domain, moreover there is no corresponding anti-discrimination law, even if there are many BL works in the commercial field, they are still "castrated" and cannot be regarded as a sign of equal rights for homosexuality. In June 2017, the China Network Audiovisual Program Service Association under the charge of the State Administration of Radio, Film and Television issued the "General Rules for the Review of Online Audiovisual Program Content", which stated that homosexuality is "showing and displaying abnormal sexual relations and sexual behaviors". It is "rendering obscene pornography and vulgar low-level taste" [5]. In June 2020, Hangzhou banned the Pride Month parade in Hangzhou because of "Sponsorship of 
Foreign Powers". In July 2021, the gay WeChat public accounts of major colleges and universities were collectively removed from the shelves [6].

In the following, the author will analyze the reasons for the delay or even retrogression of homosexual rights in China without the religious persecution of homosexuals and the reason why homosexual marriages in mainland China have not been approved from the perspective of gender: traditional thought led by Confucianism, the aversion to homosexuality under the patriarchal system, and finally analyzed the attitude and contradiction of the Chinese socialist system towards same-sex issues through the view of the second time of the women's movement that "personal issues are political issues".

\section{CONFUCIANISM'S VIEW ON HOMOSEXUAL MARRIAGE}

Professor Bai Tongdong believes that according to Zhang Xianglong's view of "Yin and Yang" in the origins of Chinese philosophy, yin and yang are equated with men and women. Especially in the relationship between husband and wife, yin and yang are a complementary relationship between men and women, the author does not think that homosexuality is evil, but the appearance of homosexuality is just a deviation caused by the insufficient combination of Yin and Yang. If the number of homosexuality is not large, it is tolerable.

Zhang Xianglong pointed out that the fundamental reason for Confucianism to oppose homosexual marriage is that it violates the principle of survival, that is, it cannot be passed down from generation to generation. "And through this principle, personal consciousness is integrated into the family's honor and disgrace, and it is necessary to make a rational decision for the "glorious ancestor". But based on this principle, Confucianism has faced similar challenges long before the emergence of homosexual marriage and modern DINK family problems, that is, the problem of unmarried and infertile Buddhists and Catholics". In this regard, Confucianism did not exclude Buddhism, because they, like homosexual marriages, are only things that a few people can control.

Although it is necessary to oppose homosexual marriage becoming the mainstream of marriage, it is still necessary to encourage heterosexual marriage through public opinion and public policies. In other words, the position of Confucianism still uses social and family responsibilities to restrict personal choices [7]. However, in recent years, China has introduced a divorce cooling-off period and liberalized the two-child and three-child policy, indicating that the family's restraint on personal choices has become less and less, and people's recognition of traditional concepts such as inheritance and harmony between husband and wife has declined, and they are more pursuing personal freedom. Confucian values are denied by the mainstream heterosexual families they value most, and the obstacles of Confucianism to homosexual marriage become minimal

\section{ANALYSIS OF THE ROOT CAUSE OF AVERSION TO HOMOSEXUAL MARRIAGE IN MODERN CHINA}

Summarizing the attitude towards homosexual marriage from traditional Confucianism is that this is a controllable choice of a few people and will not have a major impact, so it does not hold an opposite attitude. It is true that under the influence of Confucianism, ancient China adopted a tolerant attitude towards same-sex relationships, but today, when homosexuality, a modern concept generated by the construction of western culture, is introduced into China, many people will also complain that the homosexual marriage would destroy traditional families and "pass on from generation to generation". Why?

On the surface, homosexual marriage has had an impact on gender duality hegemony, making traditional gender roles and division of labor more questioned. For example, gay and lesbian couples, whose gender roles are generally more flexible, tend to have a fairer division of housework than heterosexual couples. Therefore, from the perspective of women's liberation, homosexual marriage has played a role in supporting and eliminating existing gender roles and inequality.

Fundamentally speaking, homosexuality, especially male homosexuality, poses a threat to the male homosocial desire in the patriarchy. Nochizuko mentioned in "Misogyny" that "male homosocial desire" is the bond between men who do not have a sexual relationship. To be precise, it is the bond between men who have suppressed "sexual existence". Freud divided the "desire of life" into identification and libido cathexis. The former is translated as "assimilation" and the latter is translated as "desire satisfaction" [8]. Sociological scholar Keiichi Sakuda, in the most concise terms, expressed the two as "the desire to become" and "the desire to possess". Among children, grown up in two horn-shaped families, those who desire to assimilate with their father and have a mother (substitute) act like men; and those who desire to be assimilated with their mother and have a father (substitute), act like a woman. Because they cannot have the mother in reality (which is already owned by the father), those who seek their mother's replacement as their wives become heterosexual men. At the same time, people who find that their mother has no penis (as a symbolic male sex organ) and desire the father's penis will seek his son as a substitute for the penis, thus achieving assimilation with the mother. This is a heterosexual woman. "Sexual existence" is both the 
"desire to become" and the "desire to possess", and only those who successfully invest the two on opposite-sex parents can successfully become heterosexual men or women. But there is also the possibility of "failure" in the process of its growth. According to Freud, it is a person who has failed in the differentiation of the two sexual desires, the desire to become and the desire to possess. In other words, male homosexuals are those who point both the "desire to become" and the "desire to possess" to men of the same sex [9].

To be inserted, obtained, and become a sexual object, another expression of these terms is "feminized". What men fear most is being "feminized", that is, the loss of the dominant position of sex. Men's fear of the "homosexuality" lurking in their own group is the fear that they may be regarded as sexual objects, that is, they will lose their subjective status.

Therefore, the search for homosexuality in the male group is very severe. This is "homophobia". In order to ensure the homogeneity of the male group, that is, to ensure that each member is the subject of sex, this is indispensable [10].

Of course, Chizuko Ueno did not discuss the aversion to lesbians in a patriarchal society. In my opinion, it is because lesbians are still women or in the position of second sex. They are objectified and sexualized rather than possessed. Individuals of free will, and will not threaten men's male homosocial desire. The aversion of gay men is the uneasiness of the threat to the male subject in the misogyny mechanism under the patriarchy. In contrast, the aversion of lesbians is more of Her act of escaping from the sexual object, or even subverting the status of "the other", produced aversion.

Regardless of whether China is opposed to homosexuality before, in the modern world, the moral pressure on homosexuality has not diminished. Even if homosexuality proves that it is "natural" through its "immutable" characteristics, it can unload its morality through this innate determinant. But the moral "good" derived from the "natural" is a basic logical fallacy, which is what the British ethicist Moore called the "muse of naturalism" [11].

Without freedom, there is no responsibility. Since you are powerless in your choice of sexual orientation, you do not have to bear moral condemnation, but this way of coping does not alleviate the society's negative evaluation of homosexuality. This problem is the issue of "moral avoidance" in the appeal of gay rights. It is hard to imagine that words like "morality" and "good" can support gay rights. These words are completely controlled by the conservatism that opposes homosexuality under the patriarchy, just like an away game. Supporters of homosexuality can only shy away from moral discourse, and spend a lot of effort to argue that such moral discourse should not be enforced, and they cannot argue against these moral discourses themselves [12].

In summary, the misogyny mechanism under this patriarchy and the uncriticism of homosexual moral errors makes it difficult to break through the public power and anti-identity psychology at the mass level. Therefore, whether or not the West brings the concept of equal rights to homosexuality and homosexual marriage to China, which does not originally discriminate against homosexuality, people under the patriarchal ideology will involuntarily affirm the inaccuracy of homosexuality and homosexual marriage.

\section{CONSIDERATIONS OF HOMOSEXUALITY UNDER CHINESE SOCIALISM}

Homosexual equality, like the feminist movement, is a product of modernization, and it is also a measure of whether a country is modern or not. Therefore, the state's affirmation of homosexual rights is essentially a means to prove the advanced nature of its own regime. However, these modernization symbols inevitably have a capitalist nature. For socialist countries, these modernization symbols are not conducive to eliminating bourgeois ideology and realizing proletarian culture as the dominant ideology. Therefore, when socialist countries use these symbols, they will gradually break away from the previous "bourgeois" and "narrow" frameworks and carry out "socialist" transformations to establish the legitimacy of their regimes, such as in the women's movement in modern China. The CCP uses women's liberation as a sign of its modernity.

The historian Karen Offen observed a rule in her research on European feminism: In order to win supporters, when socialist parties misappropriated feminist issues and wrote them into their programs, the strategy they adopted was to incorporate feminism. Called "bourgeois" and devalued the achievements of feminism as "narrow" [13]. This law happens to apply to the history of Chinese feminism. Vocabularies such as "narrow feminism" and "bourgeois feminism" were used shortly after the founding of the Communist Party of China. The only difference is that the CCP has added another adjective "western". The feminists of the Chinese Communist Party used the term "women's liberation movement" to demarcate the "feminist movement", claiming that the former correctly complied with the radical revolution as a prerequisite for women's liberation, while the latter mistakenly pursued women's political and legal rights without fail. Notice the evils of the existing economic and political systems.

The CCP established its regime's legitimacy by accepting women's liberation as one of its goals from the very beginning. When the united front broke down in 1927, each political party retained its own Ministry of 
Women or Women's Movement Committee. Since then, every political party has claimed that it has played a leading role in the women's movement in China. Because the new cultural feminist discourse has turned the "women's movement" into a symbol of Chinese modernity, any political force that claims to be progressive will grab it [14].

Once the CCP gained political control of the country, it implemented institutional changes. Christina Gilmartin commented in her research on the history of CCP's feminism "after 1949, a large number of CCP's language and conventions for emancipating women continued to exist. It provides a legal basis for anyone who is determined and savvy who wants to use them in this communist country " [15].

At the same time, our time is still an era in which capitalism is in a strong position as a whole. The material foundation is not strong enough to make socialist ideology mainstream, which leads to inevitably turning to the old ideology during ideological struggles with western capitalist countries. The direction is going backwards. For example, the oppression of homosexuality and women under conservatism and petty bureaucracy occurred in the Soviet Union.

Through the above thinking, analyzing the attitudes and policies of mainland China to contradictory rights and interests of homosexuality has become a breeze. In the beginning, the decriminalization and de-morbidization of homosexuality helped to prove the modernity of its own regime and gain international recognition, thereby promoting the international influence of China's reform and opening up. In recent years, with the resurgence of international conservatism, the rise of China, and the deterioration of Sino-US relations, the ideological struggle between China and the United States led by western capitalism has become more anxious, and attitudes towards homosexual rights have become contradictory: after decriminalization The growing awareness of homosexual rights in China and the pressure of international public opinion have led China to adopt a policy attitude of maintaining stability and suppressing it. It recognizes same-sex rights internationally and strives to promote the legalization of homosexual marriage in mainland China. At home, it strictly monitors gay groups and rejects same-sex on traditional grounds. The legalization of marriage, together with the feminist movement, was stigmatized by "foreign power".

\section{CONCLUSION}

To sum up, China's recent vague and contradictory attitude towards homosexual marriage is not due to the oppression of traditional culture that causes the law to lag behind the will of the people, but the socialist ideology and patriarchy under the complex ideological struggle.
In this paper, the influence of other factors on homosexual marriage are not mentioned. For example, China's affirmative law is lagging behind. China has not yet established an anti-discriminatory employment law. Regarding homosexual marriage, the United Nations survey data show that a small number of interviewees generally support the policy of equal rights for sexual minorities. Among them, nearly $85 \%$ support the legalization of homosexual marriage. In addition, more than $80 \%$ of the interviewees agreed that the law should clearly protect the rights of sexual minorities [16].

Secondly, when the domestic economic and political turmoil and conservatism resurge, the ruler will transfer the contradiction to women and sexual minorities. For example, Russia has intensified the persecution of homosexual groups when the fertility rate and the economy are both declining. Conservative forces came to power under the influence of the economic downturn, and they also introduced a bill prohibiting abortion and homosexual behaviors to shift social conflicts and strengthen the rule of conservative forces.Although the Chinese government has not adopted this argument at present, in today's tense Sino-foreign relations, many homosexual groups' rights solicitation and homosexual group related ngo are labelled as "foreign powers" in an attempt to stigmatize and divert contradictions. Chinese homosexaual groups are labeled as morally incorrect and politically incorrect, which makes the road to equal rights even more difficult.

\section{AUTHORS' CONTRIBUTIONS} Qiao

This paper is independently completed by Leshui

\section{ACKONWLEDGMENTS}

Throughout the writing of this paper I have received a great deal of support and assistance.

Firstly, I would like to thank my supervisor Pro Ford, whose expertise was invaluable in formulating the research questions and methodology. Your insightful feedback pushed me to sharpen my thinking and brought my work to a higher level.

Secondly, I would like to thank my parents for their wise counsel and sympathetic ear. You are always there for me.

Finally, I could not have completed this paper without the support of my friends, Xinhao Wang, who provided stimulating discussions as well as happy distractions to rest my mind outside of my research.

\section{REFERENCES}

[1] Criminal law of the people's Republic of China (Revised). Website of the National People's 
Congress of China. September 7, 2014. http://www.npc.gov.cn/wxzl/wxzl/2000-12/17/cont ent_4680.htm

[2] Non pathology of homosexuality and related documents. April 15, 2017.

https://web.archive.org/web/20180401213543/http://orig inal.tongyulala.org/download/2009/4/29/20090429 140950_11_ 6ec0489348ee70521928eaad11e06e55D(1).pdf

[3] Li Yinhe. Sex is free and happy.[J]Business week,vol 23, 2005.

[4] I do voluntary guardianship notarization for same-sex partners: they are afraid that notarization without signature during operation will be regarded as marriage certificate. Sohu News. Sept 03, 2019. https://www.sohu.com/a/330829888_one hundred and twenty million one hundred and forty-six thousand four hundred and fifteen.

[5] General rules for content review of online audio-visual programs. Surging news. Jun 30, 2017.

https://www.thepaper.cn/newsDetail_forward_one million seven hundred and twenty-one thousand seven hundred and seventy-seven.

[6] Voice of America. Wechat's deletion of LGBT accounts of Chinese college students raises concerns about suppressing gay culture. Jul 07, 2021.

https://www.voachinese.com/a/WeChat-deletes-Ch inese-university-LGBT-accounts-in-fresh-crackdo wn-20210707/5956439.html

[7] Bai Tongdong. How does Confucianism recognize same-sex marriage- And discuss with Professor Zhang Xianglong.[J] Journal of Renmin University of China, issue 2, 2020.

[8] Henry Abelove. Freud, Male Homosexuality, and the Americans [J] Studies in Gender and Sexuality, vol 17, no2, 2016.

[9] Eve Kosofsky Sedgwick.Between Men: English Literature and Male Homosocial Desire (translated by Guo Jie, Shanghai Sanlian bookstore, 2011) [M]Jul 19, 2011.

[10] (Japan) Ueno qianhezi. Misogyny (translated by Wang Lan)[M] Shanghai Sanlian Bookstore

[11] G. E. Moore: Principia Ethica [M] Dover Publications. Aug 30, 2004.

[12] Guo Xiaofei. Research on equal protection of sexual / other minorities [M] China University of political science and Law Press, Sept 01, 2018.
[13] Karen Offen. European Feminism (s): 1700-1950 [M] Stanford: Stanford University Press.University of California Press, 1999.

[14] Wang Zheng.Women in the Chinese Enlightenment: Oral and Textual History [M] University of California Press, 1999.

[15] Christina Kelley Gilmartin. Engendering the Chinese Revolution: Radical Women, Communist Politics, and Mass Movement in the 1920s [M] University of California Press, 1995.

[16] Survival status of sexual minorities in China survey report on social attitudes based on sexual orientation, gender identity and gender expression, United Nations Development Programme, 2016. https://www1.undp.org/content/dam/china/img/de mgov/Publication/UNDP-CH-PEG-Being LGBT in China_CH.pdf. 